(Revised)

\title{
Innovation, Ownership and Profitability
}

\author{
James H Love ${ }^{1}$, Stephen Roper ${ }^{2}$ and Jun Du ${ }^{1}$ \\ ${ }^{1}$ Economics and Strategy Group, Aston Business School, Aston University, \\ Birmingham, B4 7ET, UK \\ Email: j.h.love@aston.ac.uk; j.du@aston.ac.uk \\ ${ }^{2}$ Centre for Small and Medium Sized Enterprises, Warwick Business School, \\ University of Warwick, Coventry, CV4 7AL, UK. \\ Email: stephen.roper@wbs.ac.uk
}

\begin{abstract}
This paper considers the relationship between innovation, ownership and profitability for a panel of manufacturing plants in Ireland and Northern Ireland. Previous literature suggests that innovators are persistently more profitable than noninnovators, but little is known about how this link is moderated by external versus domestic ownership. We consider the link between innovation and profits separately for indigenous innovators and non-innovators and externally-owned plants. We also consider the determinants of innovation over the distribution of plant-level profitability, and find that the determinants of profitability - including innovation and external ownership - vary over the distribution from low to high profitability plants. We find support for the view that innovators and non-innovators have different profitability determinants, and that the profitability of externally-owned plants depends on very different factors to those of indigenously-owned enterprises.
\end{abstract}

\section{Acknowledgements}

This research was undertaken as part of a project funded by the ESRC (Award RES000-22-0729). We are grateful for the constructive comments of Monica Giulietti and an anonymous referee.

Keywords: Innovation; Ownership; Profitability; Ireland; Northern Ireland

JEL Codes: O32, F14, L60 


\section{Innovation, Ownership and Profitability}

\section{Introduction}

Research on the link between (product) innovation and profitability at the firm or establishment level suggests that innovators are persistently more profitable than noninnovators (Geroski et al., 1993; Leiponen, 2000; Cefis and Ciccarelli, 2005). This may arise because innovators, due perhaps to their market position, are able to protect their new products from the competition which normally erodes such profits, or because innovating firms are able to introduce multiple innovations over time, and are therefore able to maintain high profits although the profit effect of any individual innovation may be transitory. The empirical evidence here is mixed. Both Geroski et al. (1993) and Leiponen (2000), for instance, conclude that the profitability effects of individual innovations are relatively transitory, and that innovators are persistently more profitable than non-innovators because they have superior internal capabilities. By contrast, in an analysis of the US pharmaceutical industry, Roberts (1999) finds evidence of a 'conveyor belt' of new products, each of which provides only a temporary monopoly position, but which collectively result in persistently high profits among innovating firms.

In the case of economies such as Ireland, where a significant element of productive capacity is externally-owned, making general inferences about the relationship between innovation and profitability is complicated by two further issues. First, foreign-owned enterprises tend to be more productive (and by implication more profitable) than their indigenous counterparts (Stone and Peck, 1996; Griffith et al., 2004) largely because they are more technologically advanced (Oulton 2001) ${ }^{1}$. So,

\footnotetext{
${ }^{1}$ Birnie and Hitchens (1998), for example, comparing Census of Production data from Ireland and the UK, suggest that in 1989: manufacturing productivity in externally-owned firms in Ireland was 69 per cent above that of externally-owned firms in the UK, while indigenously-owned firms in Ireland lagged 8 per cent behind indigenously-owned firms in the UK; the productivity differential between externally-owned and indigenously owned firms in Ireland was 178 per cent compared to 52 per cent in the UK. Similarly, Cassidy (2004) in his recent review of Irish productivity growth concludes that: 'Ireland's superior productivity performance in manufacturing has been largely a consequence of two factors, namely higher productivity growth in the high-technology sectors than the European average and also a greater degree of specialisation in these sectors' (p.93).
} 
there may be differences between the profitability of indigenous and foreign plants regardless of their product innovation performance. Secondly there is evidence of a link between foreign ownership and innovation, with the balance of evidence suggesting that externally-owned firms are generally more likely to be innovative than indigenously-owned firms in terms of both products (Harris and Trainor, 1995; Love and Ashcroft, 1999), and their adoption of new process technologies (Hewitt-Dundas et al., 2002). Thus, not only may innovators be different from non-innovators in terms of their organisational or internal capabilities aside from innovation, but externally-owned plants may be different from indigenously-owned plants partly as a result of innovation performance, complicating the innovation-profitability relationship.

In this paper we consider the relationship between innovation and profitability for a large sample of manufacturing plants in Ireland and Northern Ireland. The economies of both Ireland and Northern Ireland are heavily weighted towards externally-owned enterprises with, for example, 50.5 per cent of employment and 81.9 per cent of value added being accounted for by externally-owned firms in manufacturing and tradable services in Ireland in 2005 (Forfás, 2006) ${ }^{2}$. So, in order to allow for these differences, we consider not only the link between innovation and profits but do so separately for innovators and non-innovators, and for indigenously-owned and externally-owned plants $^{3}$. Because of the tendency for considerable enterprise-level heterogeneity in performance even within industries (Bartelsman and Doms, 2000; Goddard et al., 2006), we also consider the determinants of innovation over the distribution of plantlevel profitability, and find that the determinants of profitability - including the impact of innovation and external ownership - vary over the distribution from low to high profitability plants. Our analysis also provides support for the view that innovators have different capabilities from non-innovators, even among indigenous

\footnotetext{
${ }^{2}$ The extent of externally-owned productive capacity in Northern Ireland is less clear with published figures identifying 724 foreign-owned firms operating in Northern Ireland in 2005 (DETI, 2005). Around a third of these plants are owned by firms with headquarters in Ireland and a further quarter by US firms. No figures are published, however, for the number of plants in Northern Ireland owned by UK firms with headquarters in other regions (see Hewitt-Dundas et al., 2005 for a more detailed discussion).

${ }^{3}$ For Ireland, a nation state, the terms 'externally-owned' and 'foreign-owned' are of course synonymous. For Northern Ireland, 'externally-owned' plants include all those which are 'foreignowned' but also those which are headquartered in other UK regions. Throughout the paper our discussion relates to this wider group of externally-owned plants.
} 
plants, and that it is these capabilities, rather than innovation per se, that explains their superior profitability. In addition, however, we find that externally-owned plants have a quite different set of profitability determinants from indigenously-owned plants, and that this is not related directly to innovation being conducted in the Irish plant.

\section{Linking ownership, innovation and profitability}

This section briefly reviews the empirical evidence on the three sets of relationships that are relevant to the present research: the link between innovation and profitability; the link between external ownership and performance; and, the link between external ownership and innovation. We develop a simple model linking these three influences which provides the basis for our empirical analysis

\section{Innovation and profitability}

A considerable empirical literature has considered the link between R\&D inputs, innovation and firm profitability. The consensus is overwhelmingly of a positive relationship, but with some debate about the precise nature of the relationship.

Using UK firm-level data from 1972-83, Geroski and Machin (1992) and Geroski et al. (1993) find that there are positive effects of firm-level innovation on profits, but these are relatively small and transitory. Indirect effects are larger and more long lasting: that is, it is the process of innovation that really matters for profitability (i.e. the transformation of internal capabilities), rather than the returns from individual innovations. The fact that innovators persistently earn higher profits than noninnovators is a result of three components: a small, transitory difference associated with the production of specific innovations; a substantial permanent difference (improved capabilities though the process of innovating); and a large cyclical component (non-innovators' profit margins are more sensitive to trade cycle than those of innovators). 
Subsequent studies have built on this work, particularly on the idea that the process of innovation helps build the internal capabilities of firms. Another UK study, this time for the period 1988-92, also finds that innovators are persistently more profitable than non-innovators, and that the gap is greater between persistent innovators and noninnovators (Cefis and Ciccarelli, 2005). Cefis and Ciccarelli (2005) also find that innovation has a positive effect on profitability which decreases over time (i.e. there is a decay effect). Using data for Finnish manufacturing firms, Leiponen (2000) is able to assess the profitability effects of both process and product innovation, and finds that while process innovation has a positive effect on profitability product innovation has a negative effect. Leiponen also finds that the profitability of innovators and noninnovators are determined by different factors, with competencies built on knowledgebased factors being much more important for innovators.

Canadian data appear to confirm the positive relationship between $\mathrm{R} \& \mathrm{D} /$ innovation and profitability. Using data on 278 quoted Canadian companies, Hanel and St-Pierre (2002) find that firm-level R\&D capital has a positive (but lagged) effect on profitability, and that this effect is especially strong in sectors in which the firm is able to appropriate the results of its own $R \& D$ activity i.e. where there is effective patent protection. This latter finding raises the issue of whether the persistently higher profits of innovators relative to non-innovators arises because firms introduce new products which are somehow protected from the competition which normally erodes such profits (an anti-competitive effect) or because firms successfully introduce multiple innovations over time, and so are able to maintain high profits although the profit effect of any individual innovation is transitory (an innovation effect).

Roberts (1999) specifically examines these competing explanations for US pharmaceutical firms from 1977 to 1993, and finds strong support for the latter effect: US pharmaceutical firms are adept at bringing forward a conveyor belt of new products each of which provides only a temporary monopoly position, but which collectively provide persistently high profits at the firm level. There is little support for the anti-competitive hypothesis in this sector: however, there may be some doubt about the generalisability of Roberts' findings. The pharmaceuticals industry is one largely predicated on the continuous search for new products, which is not a feature of 
other industries. For example, using a large database of innovations over the period 1945-82, Geroski et al. (1997) look for evidence of ‘dynamic economies of scale' i.e. the possibility that increases in the volume of innovations produced by a firm in one time period increases the likelihood that it will continue to innovate subsequently. They find very little evidence that innovative activity is self-sustaining: it is very rare for firms to innovate persistently, and even the ones that do so do not innovate over long periods.

\section{External ownership and performance}

There is strong theoretical and empirical evidence of a positive link between external ownership and business performance. The traditional starting point for considering the determinants of foreign direct investment (FDI) from the perspective of the firm involves the assumed possession of some competitive or 'ownership' advantage, often knowledge-based. The public good nature of these firm-specific assets may make international exploitation of the advantage by contractual means hazardous, thus giving an incentive to engage in FDI (Buckley and Casson, 1976; Dunning, 1988; Horstmann and Markusen, 1996).

The consensus of the empirical literature supports the view that externally-owned plants are more productive than their indigenous counterparts, even within advanced industrialised economies (Caves, 1996; Oulton, 2001; Griffith et al., 2004). There are a few caveats, however. Globerman et al. (1994), for example, find that multinationals in Canada are not significantly more productive than Canadian domestically owned firms after controlling for capital intensity and size, hence they suggest that the superior performance of externally-owned plants is due to their high capital intensity and large size. Driffield and Girma (2003) find that although externally-owned firms in the UK are more productive, they pay higher wages to an extent that outweighs the productivity advantages.

A substantial body of academic research has recognized and documented the contribution of multinational firms to the Irish economy (e.g. Barry and Bradley, 1997; Love and Roper, 2001; Görg and Strobl, 2002, 2003; Girma et al., 2004; 
Cassidy et al., 2005). For example, Cassidy et al. (2005) analyse productivity determinants using Irish plant-level survey data over 1999-2002 for plants with at least 10 employees. They find that both domestic and foreign-owned exporting plants tend to be more productive (in TFP terms) than their non-exporting counterparts, with the results being stronger for foreign firms than domestic ones. And, Girma et al. (2004) compare the productivity of purely domestic plants, domestic exporters and domestic multinationals in Ireland, and find evidence that the distribution of performance of domestic multinationals dominates that of other groups of firms ${ }^{4}$.

\section{External Ownership and Innovation}

Conceptually, the literature on the link between external ownership and innovation suggests the effect could be positive or negative, depending on whether the beneficial effects of access to group resources outweigh the potentially detrimental 'branch plant' effect. Externally-owned plants may have access to technological resources such as access to large-scale R\&D facilities operated by the parent, or to proprietary knowledge developed by the parent (Brugger and Stuckey, 1987) ${ }^{5}$. Alternatively, access may be available to a wide range of non-scientific resources such as finance, an international marketing organisation through which new products can be diffused, or through patenting or other support functions. On the other hand, the 'branch plant' literature suggests that externally-owned plants are less likely to have in-situ R\&D facilities on which innovation crucially depends. For example, early work by Malecki (1980) and Howells (1984) suggests that the location of R\&D is likely to be heavily influenced by corporate decisions, with basic scientific research, for example, typically assumed to be the most scale-intensive activity and therefore more likely to be centralised by the parent company than applied research and development work.

The limited empirical evidence on this issue appears to suggest that, on balance, a positive effect of external ownership on innovation is likely. Harris and Trainor

\footnotetext{
${ }_{5}^{4}$ Note, however, that this may be more an issue of multi-nationality than of foreign ownership.

${ }^{5}$ The evidence suggests that Ireland benefits disproportionately from this type of inward knowledge or technology transfer. OECD provides figures on the Technology Balance of Payments (TBOP) which reflects the balance of inward and outward knowledge transfer through patents, licensing etc. Countries such as Finland and Denmark with historically higher levels of business and university R\&D both have small positive TBOPs (c. 0.1 per cent of GDP) while Ireland has a TBOP deficit (i.e. net inward transfer) equivalent to 10.5 per cent of GDP.
} 
(1995) conclude that externally-owned plants in Northern Ireland are more likely to innovate, at least in part because they devote more resources to R\&D. This conclusion is supported by Love et al. (1996) and Love and Ashcroft (1999), who find evidence that foreign-owned manufacturing plants in Scotland (but not other UKowned plants) are more likely to innovate than their indigenous counterparts. In an analysis of innovation among UK, German and Irish manufacturing plants, Love and Roper (2001) find that external ownership generally has a negative effect on innovation intensity (number of innovations per employee); in Germany and Ireland, however, external ownership is positively associated with innovation success (the proportion of sales attributable to new products). The implication is that although plants which are externally owned tend to make relatively fewer innovations than indigenously owned enterprises, these innovations are typically more successful commercially.

The consensus from these three separate strands of literature appears to be as follows. First, innovation is positively linked to profitability. Although the precise nature of the relationship is unclear, it appears to be linked to the superior capabilities of innovators. Secondly, externally-owned enterprises generally perform better than domestically-owned enterprises (although this is not always the case), and Ireland has benefited considerably from the employment and spillover effects of this superior performance. And finally, externally-owned plants are more likely to innovate, but may not innovate more, than indigenous plants. A straightforward representation of these interactions is as follows

$$
\begin{aligned}
& \pi_{i t}=\beta_{0}+\beta_{1} I_{i t}+\beta_{2} O_{i t}+\beta_{3} \boldsymbol{X}_{i t}+\mu_{i t} \\
& I^{*}{ }_{i t}=\alpha_{0}+\alpha_{1} O_{i t}+\alpha_{2} \text { Sit }+\varepsilon_{i t}
\end{aligned}
$$

where $\pi_{i}$ is profitability of plant $\mathrm{i}$ at time $\mathrm{t}, \mathrm{I}_{\mathrm{it}}$ is innovation, $\mathrm{O}_{\mathrm{it}}$ is plant ownership, $\boldsymbol{X}_{\mathrm{it}}$ is a vector of other determinants of profitability, and $\boldsymbol{S}_{\mathrm{it}}$ a vector of other determinants of innovation and we anticipate $\beta_{1}, \beta_{2}, \alpha_{1}>0$. Although simple, this formulation has two desirable features. First, it allows for both effects of ownership identified in the empirical literature: the direct effect of ownership on profitability and its indirect effect through innovation. Secondly, it allows for the possibility of innovators having systematically better profitability performance than non-innovators, 
perhaps as a result of superior capabilities. Equations (1a) and (1b) can therefore be thought of in terms of a treatment model in which $I_{i t}$, the endogeneous binary decision variable, is assumed to stem from the unobserved latent variable $I_{i t}^{*}$. The decision to obtain the treatment (i.e. the decision to innovate) is made according to

$$
I_{i t}=\left\{\begin{array}{l}
1, \quad \text { if } I_{i t}^{*}>0 \\
0, \text { otherwise }
\end{array},\right.
$$

where $\varepsilon_{i t}$ is the error term of equation (1b), and $\mu_{i t}$ and $\varepsilon_{i t}$ are assumed to follow a bivariate normal distribution with mean zero and covariance matrix $\left[\begin{array}{cc}\sigma & \rho \\ \rho & 1\end{array}\right]$.

In the empirical analysis we use a model based on the formulation above to estimate the impact of ownership and innovation on profitability for a large sample of Irish manufacturing firms.

\section{Data and Estimation Procedure}

Our empirical analysis is based on data from the Irish Innovation Panel (IIP) which provides information on the innovation, technology adoption, ownership and performance of manufacturing plants throughout Ireland and Northern Ireland over the period 1991-2002. The IIP comprises four linked surveys conducted using similar postal survey methodologies, sampling frames provided by the economic development agencies in Ireland and Northern Ireland, and questionnaires with common questions. Each survey covers the innovation activities and performance of manufacturing plants with 10 or more employees over a three year period with an average survey response rate of 34.5 per cent $^{6}$. In our analysis here we use the second, third and fourth waves of the survey covering the period 1994-2002, with descriptive statistics given in Table 1a. As a result of the separate sampling process for the various waves the panel is unbalanced, with 2002 observations from 1494 plants ${ }^{7}$.

\footnotetext{
${ }^{6}$ Details of each wave of the survey can be found in Roper et al. (1996), Roper and Hewitt-Dundas (1998), Roper and Anderson (2000), Roper et al., (2004).

${ }^{7}$ The unbalanced nature of the panel means we cannot be sure if non appearance of a plant in a particular wave is a result of non-response or closure. This means that issues such as e.g. survivor bias
} 
The empirical implementation of the treatment model follows the standard literature in terms of dependent and independent variables. The profitability equation (1a) uses a simple market structure-firm performance model augmented by indicators of innovation and ownership and other characteristics which are known to be linked to profitability such as plant vintage and capital intensity (Geroski et al.,1993; Leiponen, 2000). Following the innovation production function literature (Crépon et al., 1998; Lööf and Heshmati, 2002; Roper et al., 2006), the innovation equation (1b) allows for R\&D and other sources of knowledge inputs as well as ownership and scale effects. The empirical model is thus of the form:

$$
\begin{gathered}
\log \pi_{i t}=\beta_{0}+\beta_{1} M_{j t}+\beta_{2} I_{i t}+\beta_{3} O_{i t}+\beta_{4} C_{i t}+\mu_{i t} \\
I_{i t}^{*}=\phi_{0}+\phi_{1} S I Z E_{i t}+\phi_{2} R D_{i t}+\phi_{3} K S_{i t}+\phi_{4} O_{i t}+\varepsilon_{i t}, \quad \mathrm{k}=1,4 \\
I_{i t}=\left\{\begin{array}{c}
1, \quad \text { if } I_{i t}^{*}>0 \\
0, \text { otherwise }
\end{array}\right.
\end{gathered}
$$

The set of market structure variables $\left(\mathrm{M}_{\mathrm{jt}}\right)$ comprises three elements. The first is a Herfindahl index measured by the sum of squares of plants' market share in terms of sales in each two-digit industrial sector (j) in each wave of the IIP survey (HHI). The second market structure indicator is a measure of the average innovation intensity of the two-digit sector of which the plant is part (measured as the mean proportion of total sales derived from products newly introduced in the last three years). And finally, we employ a series of two-digit dummy variables to capture other sectoral variations such as appropriability conditions. Economically and statistically, the concentration measure proxied by HHI captures different information from the set of industrial dummies (see Appendix Table A2).

Innovation $\left(\mathrm{I}_{\mathrm{it}}\right)$ in the IIP is represented by two variables. For the first (binary) variable an innovator was defined as an establishment which had introduced any new or improved product or process during the previous three years. Over the whole sample, 62.5 per cent of plants were product innovators while 59.2 per cent were 
process innovators (Table 1a). Notably, however, the overlap between the group of product and process innovators was not complete: around 70.2 per cent of product innovators were also process innovators, with 75.3 per cent of process innovators also being product innovators. The second innovation output measure is the proportion of plants' total sales (at the end of each three year period) derived from products newly introduced during the previous three years. This variable - 'innovation success' reflects not only plants' ability to introduce new products to the market but also their short-term commercial success. On average, 15.1 per cent of plants' sales were derived from new products across the IIP (Table 1a).

Indicators of ownership $\left(\mathrm{O}_{\mathrm{it}}\right)$ are dummy variables representing externally-owned plants with headquarters in the UK, US and elsewhere respectively. Other plant characteristics $\left(\mathrm{C}_{\mathrm{it}}\right)$ include measures of employment size, age, capital intensity, export intensity, labour qualifications, and market share (proportion of sales per twodigit sector).

The innovation equation (2b) includes firm size (SIZE) and its square, R\&D $\left(R D_{i t}\right)$, external knowledge sourcing activitities $\left(K S_{i t}\right)$, and ownership status $\left(O_{i t}\right)$. Four different types of external knowledge sourcing activity which are found to shape firms' innovation behaviour are included: forward linkages to customers (Joshi and Sharma, 2004); backward links to either suppliers or external consultants (e.g. Horn, 2005; Smith and Tranfield, 2005); horizontal linkages to either competitors or through joint ventures (Hemphill, 2003; Link et al., 2005); and linkages to universities or other public research centres (Roper et al., 2004). To test the likely causal effect of ownership on innovation suggested in the literature, we allow for the firm's ownership status in the decision-making process of engaging in innovation.

The measure of profitability is also derived from the IIP and is defined as sales less the cost of materials, labour and capital inputs. Average profitability across the final three waves of the IIP was $£ 1.76 \mathrm{~m}$, or 19 per cent of sales. Two notes of caution are worth highlighting, however, about our profitability indicator. First, it is clear from Table 1 and previous studies that the heterogeneity of profit rates even within sectors can be substantial reflecting evidence of substantial variations in firm performance 
within Irish industries (Anyadike-Danes and Heller, 2006). Second, there is substantial evidence of issues relating to transfer pricing in externally-owned businesses in Ireland. This can substantially distort both the cost of inputs purchased by plants - particularly inputs or technology 'purchased' by Irish plants from their parent companies - and/or the value of sales made by externally-owned Irish plants to other group plants or the marketing and sales units of their firms. For example, if an Irish branch is not fully charged for the cost of such external activities, this will artificially raise its recorded value-added or productivity. To achieve this they can supply inputs to the Irish branch from other parts of the firm at relatively low prices, or they can sell products from the Irish branch to other parts of the firm at relatively high prices. In either case this would tend to artificially raise the recorded level of value-added or turnover per employee in the Irish branch, a pattern which may be encouraged by relatively low rates of corporation tax in Ireland.

Table $1 \mathrm{~b}$ shows descriptive statistics separately for non-innovators versus innovators and indigenously-owned versus externally-owned plants respectively. There is a strong similarity in the patterns of characteristics: innovators/externally-owned plants are larger, more capital intensive, have more highly qualified staff, are more export intensive and have higher market shares than non-innovating/indigenous plants. Innovators are also nearly twice as likely to be externally-owned as non-innovators, and externally-owned plants are significantly more likely than indigenously-owned plants to be innovators, illustrating the links between innovation and external ownership. However, there is no evidence of profitability differences between the groups: indeed the mean profitability is almost identical between the different groups, although with a large degree of heterogeneity in profitability performance.

Two main econometric issues arise in operationalising equation (2a) and (2b): potential endogeneity of the innovation output measures, and heterogeneity in performance outcomes. The potential endogeneity of innovation output measures in models of business performance has been discussed extensively in the literature, and a range of potential approaches have been adopted including two-stage estimation methods (e.g. Crépon et al., 1998) and the simultaneous estimation of the innovation and augmented production functions (e.g. Lööf and Heshmati, 2002). Here we deal 
with potential endogeneity in innovation in two ways. First, through the treatment effect, and secondly through the fact that the IIP incorporates a built-in lag between innovation and performance, with profitability at time $t$ being related to innovation over the previous three years ${ }^{8}$.

In terms of heterogeneity, it is clear that very large variations can exist in business performance, and especially in profitability, across sectors. Recent studies of firmlevel performance have documented the large and persistent heterogeneity across firms even within fairly narrowly defined industries (Bartelsman and Doms, 2000; D'Este, 2005; Goddard et al., 2006), and this is apparent in the profitability statistics shown in Table 1. Under conditions of persistent profit heterogeneity, merely considering the conditional mean function of the dependent variable may obscure important aspects of the relationship between dependent and independent variables. For example, in the case of innovation and profitability one might reasonably expect product innovation to have variable effects on plants at different points of the profitability distribution. As noted in some applied work (for example Girma and Görg, 2005), methods such as quantile regression have been used to deal with this problem (Koenker and Bassett, 1978). Quantile regression allows one to trace the entire conditional distribution of plant level productivity, conditional on the set of regressors, and has the additional advantage of providing a more robust and efficient alternative to least squares estimators when the error term is non-normal. This is relevant in the present case as plant-level profitability is clearly not (log)normally distributed either for the sample overall or for its subsets (see Appendix). In the analysis below we therefore employ quantile regression in addition to the standard panel regression estimation.

Various approaches can be used to estimate the treatment-effects model (2a) and (2b). A two-step consistent estimator (Maddala, 1983, pp117-122) estimates (2b) as a probit model in the first step, and augments equation (2a) with a hazard function

\footnotetext{
${ }^{8}$ The empirical model effectively assumes that ownership is exogenous to both innovation and profitability. In the context of the relatively short panel in operation this is justifiable: in practice, less than two percent of plants change ownership during the period of the study. In the longer run there may, of course, be a more general relationship both between profitability and subsequent innovation performance, and between performance and ownership i.e. the most profitable/innovative plants may become the subject of external takeover.
} 
computed by the estimates of (2b). However, we opt to apply the full maximum likelihood estimation (Greene, 2005, pp787-789), which delivers more efficient estimates.

\section{Results of Estimation}

The initial estimations (Table 2) provides a baseline for exploring the innovationprofitability relationship for our entire sample of plants (column 1). Size and capital intensity have significant coefficients. There is also some impact on profitability arising from the country of ownership: non-US externally-owned plants are significantly less profitable than indigenously-owned or UK/US-owned plants. The effect of innovation is clear: being an innovator makes a plant more profitable, even after allowing for the (significant) treatment effect of innovation. However, there is no profitability boost from additional innovation: the inclusion of the extent of innovation (i.e. proportion of new products as a proportion of total sales) proved insignificant in all estimations (not shown).

Quantile regression estimations (Table 2, columns 2-6) shed further light on the roles of innovation and ownership. Results are shown for plants in the $10^{\text {th }}, 25^{\text {th }}, 50^{\text {th }}$ (median), $75^{\text {th }}$ and $90^{\text {th }}$ percentiles of the profitability distribution. Innovation shows a significant effect only for plants at or below median profitability, suggesting that the less profitable plants obtain the greatest benefits from innovation, and the positive effect becomes insignificant for plants much above median profitability. The quantile estimations also demonstrate that some variables which appear insignificant overall do have significant effects on some parts of the profitability distribution. For example, export intensity is positively linked to profitability for plants at or above the $75^{\text {th }}$ percentile of the distribution. This conforms with previous research suggesting a positive association between exporting and performance, although there remains some ambiguity about the direction of this effect (e.g. Greenaway and Kneller, 2004).

Workforce qualifications also demonstrate significantly positive effects on profitability for plants at the upper end of the distribution of profitability. 
The models outlined in Table 2 provide clear evidence of both an innovation and an ownership effect on profitability. But the question remains of how this occurs. Is the innovation effect the same for both indigenous and externally-owned plants? And, if not, given the link between ownership, innovation and profitability indicated by Table 2, are externally-owned innovators different in some way from indigenously-owned innovators?

To tackle the first of these issues Tables 3 and 4 show profitability estimations derived from the treatment model conducted separately for indigenous and externallyowned plants. The determinants of profitability are quite different. The size and innovator effects noted earlier apply exclusively to indigenous plants ${ }^{9}$, which also display significant sectoral influences (Table 3). In addition, for indigenous plants there is a significant treatment effect with respect to innovation, suggesting that among indigenous plants innovators differ from non-innovators for reasons other than innovating per se. Externally-owned plants have a quite different set of profitability determinants (Table 4). What matters for these plants is not the boost they get from innovating (there is none) but instead their position in both the domestic and export markets. These plants reap profits by having a high market share (except, interestingly, for the most profitable decile), and by avoiding markets which are highly concentrated. The export intensity effect noted in Table 2 is also exclusively the domain of externally-owned plants: export intensity is associated with higher profitability at or above median profitability levels. Sectoral influences are entirely absent in the case of externally-owned plants: the choice of industrial sector does not influence their level of profitability, as it does for indigenously-owned plants. In this estimation it is also clear that US-owned plants are more profitable than UK or other non-US owned plants, at least for the median quantile. Finally, there is no evidence of a significant innovation treatment effect for externally-owned plants. This is hardly surprising, as almost all externally-owned plants are innovators.

Indigenous and externally-owned plants thus have quite different determinants of profitability, and even after allowing for selectivity among innovators, these

\footnotetext{
${ }^{9}$ Employment shows a U-shaped relationship with respect to profitability. The turning point is c. 420 employees compared with a mean employment for indigenous plants of 63, suggesting ceteris paribus a negative relationship between size and profitability for indigenous plants.
} 
differences are not conditioned by innovation per se. Indeed, innovation plays no role in the profitability of either externally-owned plants or of the mot profitable indigenous plants. The final element is to determine whether indigenous innovators differ in their profitability determinants from both indigenous non-innovators and from externally-owned innovators.

Table 5 shows the results of estimations carried out with the sample split into these three groups. The results are striking. For indigenous non-innovators only the sector matters. Profitability in these enterprises is dictated wholly by the sector they are in, with plants having virtually no means of differentiating their profitability from the norms of the sector. Broadly, these plants are swept along by the industry, achieving levels of profitability which appear not to differ systematically from industry average levels. By contrast, indigenously-owned innovators are able to differentiate their profit performance from sectoral norms to some extent. Apart from innovation itself, for these plants market concentration and (low) capital intensity are key influences on profitability: by contrast industry effects are slight. So indigenous innovators are able to insulate themselves to some extent from market influences: the structure of the market matters more than the market in which the firm is operating, while the reverse is true for non-innovators. Indigenously-owned innovators have greater profitability if they are relatively small and labour intensive, suggesting the benefit of being a small, nimble niche operator which is prepared to introduce new products. Nonindigenous innovators (Table 5 column 3 ) show virtually identical profitability determinants to those of externally-owned plants as a whole (c.f. Table 4), with a total absence of industry sector effects.

The main empirical conclusions of the estimations in Tables 2 to 5 are that the determinants of innovators' profitability are different from those of non-innovators even among indigenously-owned plants, and that externally-owned plants are totally different from both. Therefore (indigenous) innovators have different determinants of profitability from (indigenous) non-innovators, and that this does not arise merely from the fact of being an innovator. This in turn lends prima facie support to the findings of Gersoski et al. (1993) and Leiponen (2000) that innovators and noninnovators differ in ways that are linked to the transformation of capabilities provided 
by the process of innovating rather than directly to the quasi-monopoly effects of individual innovation events. Externally-owned innovators (virtually the same as the group of externally-owned plants) are not at all like indigenous innovators: they behave entirely differently and are subject to different profitability determinants.

\section{Conclusions}

Although there is a substantial body of literature on the link between innovation and profitability, there is very little evidence on the inter-relationship between innovation, ownership and profitability. The present analysis therefore sheds further light on, for example, the differences between innovators and non-innovators, while allowing for the influence of ownership.

Our results suggest that, in profitability terms, innovators are not simply plants that innovate: their level of profitability is subject to different determinants from those of non-innovators. Innovators are able to insulate themselves from market forces to some degree: in the case of indigenous plants, at least part of which is because of innovating itself. However, the fact that product innovation per se has a negligible effect on the profitability of indigenous innovators at the upper end of the profitability distribution supports the view that it is not the quasi-monopoly rents of innovation which distinguishes the most profitable innovators from the rest, but the fact that these plants have capabilities or competences which others lack. These capabilities may be linked the process of innovation, but they are unlikely to be solely related to innovating. There is thus support for the view of Geroski et al. (1993) and Leiponen (2000) that innovators are different from non-innovators, but the quantile regression results appear to provide little support for the view of Roberts (1999) and the 'conveyor belt' hypothesis of the link between innovation and profitability.

Equally important is that externally-owned plants, almost all of which are innovators, have markedly different profitability determinants from indigenous enterprises, and these differences are not directly linked to the fact of innovation per se. While innovation is a competitive weapon for indigenous plants, it is simply a fact of life for externally-owned plants. These plants compete, and have their profitability 
determined, in a quite different way from all indigenous plants, both innovators and non-innovators. Although market share matters for the profitability of externallyowned plants, in most respects they are not really competing against most indigenous plants at all. Indeed, for the most profitable externally-owned plants export intensity rather than domestic market share influences profitability. In terms of profitability determinants, indigenous innovators and non-innovators inhabit different parts of the same world, while externally-owned innovators (effectively foreign plants) operate in a different world from both sets of indigenous enterprises. In this sense our results reflect comments made a decade ago by Wrynn (1997) which emphasised the lack of interaction between externally-owned plants in Ireland and the nation's innovation system.

In policy terms our results suggest both optimistic and cautionary messages. On the positive side our results suggest that efforts to promote innovation activity among indigenously-owned plants are likely to have significant longer term benefits through their capability effects. This may not lead to persistent innovation (e.g. Roper and Hewitt-Dundas, 2005) but does seem likely to be leading to behavioural additionality or learning effects (e.g. Buisseret et al., 1995) which in turn are contributing to longer-term business profitability. For the development agencies in Ireland this is a reassuring result given their emphasis on developing the technological capability of indigenously-owned plants since the Culliton Report of the early-1990s. On the more negative side, the lack of any relationship in our models between the innovation activities of externally-owned plants and their (profitability) performance raises potential concerns. This finding may reflect the lack of linkages between externallyowned plants and their Irish resource base, in turn raising some worrying issues about the 'embeddedness' of much FDI into Ireland and therefore its 'stickiness' in the face of Ireland's increasing high relative cost base. Here, however, it is important to bear in mind that our analysis relates to the period 1994-2002, and much of the increase in investment in public R\&D in Ireland under the 2000-06 National Development Plan actually post-dates our study. Whether in future years externally-owned plants in Ireland will draw more strongly on the Irish innovation system remains to be seen. 
Table 1a: Summary statistics - Whole Sample

\begin{tabular}{|l|r|r|r|}
\hline Variable & N & Mean & \multicolumn{1}{|l|}{ SD } \\
\hline Profit (£000) & 1536 & 1834.651 & 5998.553 \\
Profit Margin (\%, profit/turnover) & 1536 & 0.209 & 0.192 \\
Employment (number) & 1977 & 113.187 & 248.544 \\
Vintage (years) & 1925 & 32.288 & 30.437 \\
Capital intensity (capital investment per employee) & 1661 & 5.294 & 13.954 \\
Percentage of staff with degree (\%) & 1877 & 9.099 & 12.025 \\
Export intensity (exports as proportion of sales) & 1919 & 0.266 & 0.346 \\
Market share (in sales in each sector and wave) & 1770 & 0.006 & 0.022 \\
Externally-owned plants (\%) & 2002 & 0.330 & 0.470 \\
Externally-owned plants with head quarter in the UK & 2002 & 0.060 & 0.237 \\
Externally-owned plants with head quarter in the US & 2002 & 0.094 & 0.292 \\
Externally-owned plants with head quarter in other countries & 2002 & 0.088 & 0.284 \\
Herfindahl Index (HHI, sum of squares of plants' market share in & & & \\
each sector and wave) & 2002 & 0.022 & 0.066 \\
Average product innovation success (in total sales) & 2002 & 0.155 & 0.062 \\
\hline
\end{tabular}

Source: Irish Innovation Panel, Waves 2, 3 and 4. 
Table 1b: Summary statistics - Sample sub-groups

\begin{tabular}{|c|c|c|c|c|c|c|c|}
\hline \multirow[t]{2}{*}{ Variable Definitions } & \multicolumn{3}{|c|}{ Non-innovating Plants } & \multicolumn{3}{|c|}{ Innovating Plants } & \multirow{2}{*}{ t-test } \\
\hline & Obs & Mean & SD & Obs & Mean & SD & \\
\hline Profit & 343 & 858.302 & 1906.557 & 1193 & 2115.361 & 6703.777 & $-3.432^{* * *}$ \\
\hline Profit Margin (\%, profit/turnover) & 343 & 0.212 & 0.173 & 1193 & 0.208 & 0.197 & 0.309 \\
\hline Employment (number) & 439 & 50.743 & 81.300 & 1538 & 131.010 & 275.868 & $-6.021^{* * *}$ \\
\hline Vintage (years) & 417 & 34.300 & 31.001 & 1508 & 31.732 & 30.265 & 1.525 \\
\hline $\begin{array}{l}\text { Capital intensity (capital investment per } \\
\text { employee) }\end{array}$ & 357 & 2.417 & 3.842 & 1304 & 6.081 & 15.529 & $-4.421^{* * *}$ \\
\hline Percentage of staff with degree (\%) & 408 & 6.276 & 10.323 & 1469 & 9.883 & 12.345 & $-5.401^{* *+}$ \\
\hline Export intensity (as proportion of sales) & 418 & 0.151 & 0.282 & 1501 & 0.298 & 0.355 & $-7.825^{* * *}$ \\
\hline $\begin{array}{l}\text { Market share (in sales in each sector and } \\
\text { wave) }\end{array}$ & 399 & 0.003 & 0.014 & 1371 & 0.007 & 0.024 & $-2.653^{* * *}$ \\
\hline Externally-owned plants (\%) & 441 & 0.197 & 0.398 & 1561 & 0.367 & 0.482 & $-6.771^{* *+1}$ \\
\hline $\begin{array}{l}\text { Externally-owned plants with head } \\
\text { quarter in the UK }\end{array}$ & 441 & 0.043 & 0.203 & 1561 & 0.065 & 0.246 & $-1.689^{* * *}$ \\
\hline $\begin{array}{l}\text { Externally-owned plants with head } \\
\text { quarter in the US }\end{array}$ & 441 & 0.043 & 0.203 & 1561 & 0.108 & 0.311 & $-4.159^{* * *}$ \\
\hline $\begin{array}{l}\text { Externally-owned plants with head } \\
\text { quarter in other countries }\end{array}$ & 441 & 0.050 & 0.218 & 1561 & 0.099 & 0.299 & \\
\hline & & & 0.064 & & 0.022 & 0.067 & -0.400 \\
\hline & \multicolumn{3}{|c|}{ Indigenously-owned Plants } & \multicolumn{3}{|c|}{ Externally-owned Plants } & t-test \\
\hline & Obs & Mean & SD & Obs & Mean & SD & \\
\hline Profit & 1068 & 903.754 & 1975.678 & 468 & 3959.005 & 10141.50 & $-9.448^{* * *}$ \\
\hline Profit Margin ( $\%$, profit/turnover) & 1068 & 0.211 & 0.189 & 468 & 0.205 & 0.197 & 0.579 \\
\hline Employment (number) & 1326 & 63 & 90 & 651 & 216 & 394 & $-13.522^{* * *}$ \\
\hline Vintage (years) & 1285 & 32.931 & 31.654 & 640 & 30.998 & 27.812 & 1.313 \\
\hline $\begin{array}{l}\text { Capital intensity (capital investment per } \\
\text { employee) }\end{array}$ & 1127 & 3.884 & 7.324 & 534 & 8.267 & 21.910 & $-6.042^{* * *}$ \\
\hline Percentage of staff with degree (\%) & 1261 & 7.775 & 10.739 & 616 & 11.809 & 13.922 & $-6.910^{* * *}$ \\
\hline Export intensity (as proportion of sales) & 1280 & 0.159 & 0.266 & 639 & 0.481 & 0.385 & $-21.378^{* * *}$ \\
\hline $\begin{array}{l}\text { Market share (in sales in each sector and } \\
\text { wave) }\end{array}$ & 1228 & 0.003 & 0.006 & 542 & 0.013 & 0.038 & $-9.242^{* * *}$ \\
\hline $\begin{array}{l}\text { Externally-owned plants with head } \\
\text { quarter in the UK }\end{array}$ & 1342 & 0.000 & 0.000 & 660 & 0.182 & 0.386 & $-17.261^{\star \star *}$ \\
\hline $\begin{array}{l}\text { Externally-owned plants with head } \\
\text { quarter in the US }\end{array}$ & 1342 & 0.000 & 0.000 & 660 & 0.285 & 0.452 & $-23.108^{* * *}$ \\
\hline $\begin{array}{l}\text { Externally-owned plants with head } \\
\text { quarter in other countries }\end{array}$ & 1342 & 0.000 & 0.000 & 660 & 0.268 & 0.443 & $-22.165^{* * *}$ \\
\hline \multirow[t]{3}{*}{ plants' market share in each sector/wave) } & 1342 & 0.022 & 0.064 & 660 & 0.022 & 0.070 & 0.153 \\
\hline & \multicolumn{3}{|c|}{ Overall } & & & & \\
\hline & Obs & Mean & SD & & & & \\
\hline $\begin{array}{l}\text { Average product innovation success (in } \\
\text { total sales) by industry and wave }\end{array}$ & 2002 & 0.1554 & 0.062 & & & & \\
\hline
\end{tabular}

Note: ${ }^{* * *}$ indicates significance at the $1 \%$ level. 
Table 2: Determinants of profitability: All plants

\begin{tabular}{|c|c|c|c|c|c|c|}
\hline \multirow[b]{2}{*}{ COEFFICIENT } & \multirow[b]{2}{*}{ overall } & \multicolumn{5}{|c|}{ Quantiles } \\
\hline & & 0.1 & 0.25 & 0.5 & 0.75 & 0.9 \\
\hline \multicolumn{7}{|l|}{ Plant Characteristics } \\
\hline \multirow[t]{2}{*}{ Employment } & $-0.00130^{* *}$ & 0.0000103 & -0.000113 & -0.000115 & -0.000279 & -0.000242 \\
\hline & $(0.00054)$ & $(0.00046)$ & $(0.00031)$ & $(0.00018)$ & $(0.00023)$ & $(0.00025)$ \\
\hline \multirow[t]{2}{*}{ Empl squared } & $0.0000404^{*}$ & -0.000006 & 0.00000211 & 0.00000318 & 0.00000638 & $0.000019^{* *}$ \\
\hline & $(0.000022)$ & $(0.000016)$ & $(0.000011)$ & $(0.000006)$ & $(0.0000075)$ & $(0.0000075)$ \\
\hline \multirow[t]{2}{*}{ Plant vintage } & 0.000777 & 0.0000750 & 0.000886 & 0.000773 & 0.000837 & 0.000115 \\
\hline & $(0.0014)$ & $(0.0020)$ & $(0.0012)$ & $(0.00069)$ & $(0.00081)$ & $(0.00072)$ \\
\hline \multirow[t]{2}{*}{ Capital intensity } & $-0.0991^{* * *}$ & -0.0761 & $-0.114^{* * *}$ & $-0.0972^{* * *}$ & $-0.0632^{* * *}$ & $-0.0859^{* * *}$ \\
\hline & $(0.032)$ & $(0.061)$ & $(0.033)$ & $(0.017)$ & $(0.022)$ & $(0.025)$ \\
\hline \multirow[t]{2}{*}{ Staff with degree } & -0.00177 & 0.00105 & 0.000929 & 0.00114 & $0.00507^{* *}$ & $0.00352^{*}$ \\
\hline & $(0.0033)$ & $(0.0073)$ & $(0.0037)$ & $(0.0020)$ & $(0.0023)$ & $(0.0019)$ \\
\hline \multirow[t]{2}{*}{ Export intensity } & 0.0643 & 0.0530 & 0.00242 & 0.0842 & $0.289^{* * *}$ & $0.249^{* * *}$ \\
\hline & $(0.14)$ & $(0.23)$ & $(0.13)$ & $(0.071)$ & $(0.088)$ & $(0.091)$ \\
\hline \multirow[t]{2}{*}{ Market share } & 2.056 & $3.497^{*}$ & 1.721 & 0.805 & 0.0635 & $-1.634^{*}$ \\
\hline & $(3.27)$ & $(2.09)$ & $(1.60)$ & $(0.99)$ & $(1.23)$ & $(0.94)$ \\
\hline \multirow[t]{2}{*}{ Innovator } & $2.310^{* * *}$ & 0.299 & $0.662^{* * *}$ & $0.424^{* * *}$ & 0.00820 & -0.0154 \\
\hline & $(0.090)$ & $(0.35)$ & $(0.18)$ & $(0.10)$ & $(0.14)$ & $(0.15)$ \\
\hline \multirow[t]{2}{*}{ HQ in UK } & -0.128 & -0.119 & -0.0642 & 0.0205 & 0.0523 & 0.169 \\
\hline & $(0.26)$ & $(0.31)$ & $(0.17)$ & $(0.091)$ & $(0.11)$ & $(0.11)$ \\
\hline \multirow[t]{2}{*}{ HQ in US } & 0.175 & 0.240 & 0.207 & $0.133^{*}$ & 0.0420 & 0.0155 \\
\hline & $(0.22)$ & $(0.27)$ & $(0.14)$ & $(0.080)$ & $(0.096)$ & $(0.095)$ \\
\hline \multirow[t]{2}{*}{ HQ in other country } & $-0.620^{* * *}$ & -0.400 & -0.164 & -0.118 & -0.129 & -0.115 \\
\hline & $(0.22)$ & $(0.26)$ & $(0.14)$ & $(0.076)$ & $(0.095)$ & $(0.098)$ \\
\hline \multicolumn{7}{|l|}{ Market Characteristics } \\
\hline \multirow[t]{2}{*}{ Herfindahl Index } & -0.361 & $2.802^{* *}$ & 0.539 & 0.174 & $0.882^{*}$ & 0.450 \\
\hline & $(0.73)$ & $(1.31)$ & $(0.69)$ & $(0.38)$ & $(0.45)$ & $(0.48)$ \\
\hline \multirow{2}{*}{ Sector Innovation intensity } & -2.055 & 0.670 & 1.822 & 0.730 & 0.328 & -0.216 \\
\hline & $(1.34)$ & $(2.43)$ & $(1.31)$ & $(0.73)$ & $(0.90)$ & $(0.98)$ \\
\hline Industry and Location Dumm & & & & & & \\
\hline Textiles & 0.0512 & 0.106 & 0.0599 & 0.0602 & -0.0658 & -0.171 \\
\hline & $(0.15)$ & $(0.28)$ & $(0.15)$ & $(0.081)$ & $(0.10)$ & $(0.11)$ \\
\hline Wood & 0.254 & 0.363 & $0.395^{* *}$ & $0.171^{*}$ & 0.132 & 0.100 \\
\hline & $(0.16)$ & $(0.30)$ & $(0.16)$ & $(0.089)$ & $(0.11)$ & $(0.12)$ \\
\hline Paper & $0.405^{* *}$ & $1.085^{* * *}$ & $0.901^{* * *}$ & $0.587^{* * *}$ & $0.341^{* * *}$ & 0.0704 \\
\hline & $(0.16)$ & $(0.31)$ & $(0.16)$ & $(0.090)$ & $(0.11)$ & $(0.12)$ \\
\hline Chemicals & $0.503^{* * *}$ & $1.028^{* * *}$ & $0.627^{* * *}$ & $0.513^{* * *}$ & $0.302^{* *}$ & 0.136 \\
\hline & $(0.18)$ & $(0.29)$ & $(0.17)$ & $(0.096)$ & $(0.12)$ & $(0.12)$ \\
\hline Metals & $0.415^{* * *}$ & $0.895^{* * *}$ & $0.770^{* * *}$ & $0.532^{* * *}$ & $0.291^{* * *}$ & 0.0258 \\
\hline & $(0.12)$ & $(0.22)$ & $(0.12)$ & $(0.066)$ & $(0.082)$ & $(0.087)$ \\
\hline Machinery & $0.492^{* * *}$ & $0.536^{* *}$ & $0.443^{* * *}$ & $0.333^{* * *}$ & 0.165 & 0.0817 \\
\hline & $(0.16)$ & $(0.27)$ & $(0.15)$ & $(0.082)$ & $(0.10)$ & $(0.11)$ \\
\hline Electrical & 0.307 & -0.00173 & -0.0253 & 0.0460 & 0.0406 & -0.0589 \\
\hline & $(0.22)$ & $(0.40)$ & $(0.21)$ & $(0.12)$ & $(0.15)$ & $(0.16)$ \\
\hline Transport & 0.166 & -0.161 & 0.347 & $0.319^{* *}$ & -0.0398 & -0.121 \\
\hline & $(0.27)$ & $(0.42)$ & $(0.23)$ & $(0.14)$ & $(0.18)$ & $(0.19)$ \\
\hline Northern Ireland & -0.0415 & -0.0653 & -0.0992 & $-0.101^{* *}$ & -0.0711 & -0.0156 \\
\hline & $(0.075)$ & $(0.14)$ & $(0.073)$ & $(0.040)$ & $(0.051)$ & $(0.052)$ \\
\hline Specification test for selection & $-2.125^{* * *}$ & & & & & \\
\hline & $(0.091)$ & & & & & \\
\hline Selection hazard Note 3 & & 0.0101 & $-0.302^{* * *}$ & $-0.207^{* * *}$ & 0.00228 & 0.000438 \\
\hline & & $(0.21)$ & $(0.12)$ & $(0.066)$ & $(0.091)$ & $(0.11)$ \\
\hline Constant & $-3.287^{* * *}$ & $-3.369^{* * *}$ & $-3.122^{* * *}$ & $-2.224^{* * *}$ & $-1.405^{* * *}$ & $-0.817^{* * *}$ \\
\hline & $(0.22)$ & $(0.44)$ & $(0.24)$ & $(0.13)$ & $(0.17)$ & $(0.18)$ \\
\hline Observations & 1161 & 1161 & 1161 & 1161 & 1161 & 1161 \\
\hline
\end{tabular}


of atanh(rho) is equivalent to the test of the null of rho=1. Insignificant atanh(rho) indicates that selectivity bias is negligible.

Note 3: The reported coefficient of selection hazard is lambda, the parameter estimate on the selection hazard from the augmented regression using Maddala (1983) formulas, more specifically, lambda $=$ rho*sigma, where sigma is the standard deviation of residual term in the primary equation (profitability equation in this case). 
Table 3: Determinants of profitability: Indigenous plants

\begin{tabular}{|c|c|c|c|c|c|c|}
\hline \multirow{3}{*}{ COEFFICIENT } & \multirow{3}{*}{ overall } & \multirow{2}{*}{\multicolumn{5}{|c|}{ Quantiles }} \\
\hline & & & & & & \\
\hline & & 0.1 & 0.25 & 0.5 & 0.75 & 0.9 \\
\hline \multicolumn{7}{|l|}{ Plant Characteristics } \\
\hline \multirow[t]{2}{*}{ Employment } & $-0.00569^{* * *}$ & 0.000752 & -0.000104 & $-0.00226^{* * *}$ & -0.00135 & -0.00112 \\
\hline & $(0.0016)$ & $(0.0015)$ & $(0.0010)$ & $(0.00070)$ & $(0.00086)$ & $(0.0010)$ \\
\hline \multirow[t]{2}{*}{ Empl squared } & $0.000682^{* * *}$ & 0.0000421 & 0.0000299 & $0.000355^{* * *}$ & $0.000181^{*}$ & 0.000135 \\
\hline & $(0.00026)$ & $(0.00017)$ & $(0.00012)$ & $(0.000100)$ & $(0.00011)$ & $(0.00012)$ \\
\hline \multirow[t]{2}{*}{ Plant vintage } & 0.000557 & -0.00106 & 0.000482 & 0.00103 & 0.000455 & 0.000758 \\
\hline & $(0.0015)$ & $(0.0017)$ & $(0.0013)$ & $(0.00080)$ & $(0.00093)$ & $(0.00086)$ \\
\hline \multirow{2}{*}{ Capital intensity } & -0.0561 & -0.0186 & -0.0315 & $-0.0617^{* * *}$ & -0.0270 & $-0.0632^{* *}$ \\
\hline & $(0.035)$ & $(0.059)$ & $(0.034)$ & $(0.021)$ & $(0.025)$ & $(0.030)$ \\
\hline \multirow[t]{2}{*}{ Staff with degree } & -0.000986 & 0.00660 & -0.000289 & 0.00129 & $0.00673^{* *}$ & 0.00214 \\
\hline & $(0.0046)$ & $(0.0077)$ & $(0.0045)$ & $(0.0024)$ & $(0.0031)$ & $(0.0030)$ \\
\hline \multirow[t]{2}{*}{ Export intensity } & 0.0631 & -0.0666 & -0.00386 & 0.0521 & 0.120 & 0.153 \\
\hline & $(0.16)$ & $(0.24)$ & $(0.15)$ & $(0.091)$ & $(0.11)$ & $(0.11)$ \\
\hline \multirow[t]{2}{*}{ Market share } & 6.238 & -9.789 & -8.031 & 0.110 & -1.904 & -7.165 \\
\hline & $(13.1)$ & $(14.1)$ & $(9.14)$ & $(6.91)$ & $(8.05)$ & $(7.25)$ \\
\hline \multirow[t]{2}{*}{ Innovator } & $2.149^{* * *}$ & 0.325 & $0.519^{* * *}$ & $0.391^{* * *}$ & 0.0245 & 0.0720 \\
\hline & $(0.099)$ & $(0.28)$ & $(0.18)$ & $(0.11)$ & $(0.14)$ & $(0.16)$ \\
\hline \multicolumn{7}{|l|}{ Market Characteristics } \\
\hline \multirow{2}{*}{ Herfindahl Index } & 1.022 & 1.981 & 1.085 & 0.280 & $1.011^{*}$ & $1.094^{* *}$ \\
\hline & $(0.85)$ & $(1.37)$ & $(0.84)$ & $(0.51)$ & $(0.58)$ & $(0.45)$ \\
\hline \multirow[t]{2}{*}{ Sector Innovation intensity } & $-2.855^{\star *}$ & 0.0409 & 0.972 & 0.210 & -0.728 & -0.216 \\
\hline & $(1.45)$ & $(2.27)$ & $(1.39)$ & $(0.85)$ & $(1.04)$ & $(1.09)$ \\
\hline \multicolumn{7}{|c|}{ Industry and Location Dummies } \\
\hline \multirow[t]{2}{*}{ Textiles } & 0.0999 & 0.230 & 0.171 & $0.260^{* * *}$ & 0.0521 & -0.100 \\
\hline & $(0.17)$ & $(0.28)$ & $(0.16)$ & $(0.098)$ & $(0.12)$ & $(0.13)$ \\
\hline Wood & 0.175 & $0.579^{* *}$ & $0.436^{* * *}$ & $0.381^{* * *}$ & 0.0755 & 0.224 \\
\hline & $(0.19)$ & $(0.25)$ & $(0.17)$ & $(0.11)$ & $(0.14)$ & $(0.15)$ \\
\hline Paper & $0.359 * *$ & $1.032^{* * *}$ & $0.824^{* * *}$ & $0.611^{* * *}$ & 0.203 & 0.0469 \\
\hline & $(0.17)$ & $(0.27)$ & $(0.17)$ & $(0.10)$ & $(0.13)$ & $(0.14)$ \\
\hline Chemicals & $0.629^{* * *}$ & $1.183^{* * *}$ & $0.795^{* * *}$ & $0.562^{* * *}$ & $0.287^{*}$ & 0.231 \\
\hline & $(0.23)$ & $(0.31)$ & $(0.21)$ & $(0.13)$ & $(0.16)$ & $(0.16)$ \\
\hline Metals & $0.408^{* * *}$ & $0.838^{* * *}$ & $0.852^{* * *}$ & $0.592^{* * *}$ & $0.279^{* * *}$ & 0.0870 \\
\hline & $(0.13)$ & $(0.20)$ & $(0.12)$ & $(0.077)$ & $(0.095)$ & $(0.10)$ \\
\hline Machinery & $0.466^{* * *}$ & $0.677^{* *}$ & $0.501^{* * *}$ & $0.426^{* * *}$ & $0.229^{*}$ & 0.00307 \\
\hline & $(0.17)$ & $(0.29)$ & $(0.16)$ & $(0.098)$ & $(0.12)$ & $(0.13)$ \\
\hline Electrical & $0.436^{*}$ & 0.0546 & 0.264 & $0.365^{* *}$ & 0.218 & 0.0347 \\
\hline & $(0.24)$ & $(0.33)$ & $(0.21)$ & $(0.14)$ & $(0.17)$ & $(0.19)$ \\
\hline Transport & 0.277 & 0.510 & 0.405 & $0.446^{* *}$ & 0.107 & -0.0891 \\
\hline & $(0.34)$ & $(0.47)$ & $(0.27)$ & $(0.18)$ & $(0.24)$ & $(0.23)$ \\
\hline Northern Ireland & -0.0710 & -0.112 & -0.0906 & $-0.120^{* * *}$ & -0.0732 & -0.0330 \\
\hline & $(0.078)$ & $(0.12)$ & $(0.075)$ & $(0.046)$ & $(0.057)$ & $(0.062)$ \\
\hline Specification test for & $-1.984^{* * *}$ & & & & & \\
\hline & $(0.099)$ & & & & & \\
\hline Selection hazard Note 3 & & 0.00507 & $-0.194^{*}$ & $-0.202^{* * *}$ & -0.00566 & -0.0124 \\
\hline & & $(0.18)$ & $(0.12)$ & $(0.073)$ & $(0.097)$ & $(0.11)$ \\
\hline Constant & $-2.902^{* * *}$ & $-3.263^{* * *}$ & $-2.933^{* * *}$ & $-2.188^{* * *}$ & $-1.255^{* * *}$ & $-0.869^{* * *}$ \\
\hline & $(0.24)$ & $(0.39)$ & $(0.24)$ & $(0.15)$ & $(0.19)$ & $(0.19)$ \\
\hline Observations & 809 & 809 & 809 & 809 & 809 & 809 \\
\hline Note 1: All regressions includir & time dummies & Idard errors $\mathrm{i}$ & arentheses; ** & $0.01, * * p<0.05$ & & \\
\hline Note 2: The reported selection 1 & echanism (atan & )) is the inve & nyperbolic ta & th of the correl & coefficient & \\
\hline rho between residual terms of $\mathrm{r}$ & in equation an & ection equatic & e. $\operatorname{atanh}(\mathrm{rho}$ & $5[\ln (1+\mathrm{rho}) /(1$ & 1. The test & \\
\hline $\begin{array}{l}\text { of atanh(rho) is equivalent to th } \\
\text { negligible. }\end{array}$ & test of the null & $o=1$. Insignif & $\operatorname{tatanh}($ rho $)$ & cates that selec & bias is & \\
\hline Note 3: The reported coefficien & f selection haz & lambda, the & ameter estim & on the selection & ard from & \\
\hline 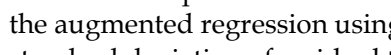 & 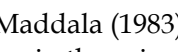 & (2) & C. 11 & . & igma is the & \\
\hline
\end{tabular}


Table 4: Determinants of profitability: Externally-owned plants

\begin{tabular}{|c|c|c|c|c|c|c|}
\hline \multirow[b]{2}{*}{ COEFFICIENT } & \multirow[b]{2}{*}{ overall } & \multicolumn{5}{|c|}{ Quantiles } \\
\hline & & 0.1 & 0.25 & 0.5 & 0.75 & 0.9 \\
\hline \multicolumn{7}{|l|}{ Plant Characteristics } \\
\hline \multirow[t]{2}{*}{ Employment } & 0.000643 & 0.000375 & -0.000216 & 0.0000852 & 0.000108 & 0.000237 \\
\hline & $(0.0011)$ & $(0.0020)$ & $(0.00098)$ & $(0.00038)$ & $(0.00040)$ & $(0.00036)$ \\
\hline \multirow[t]{2}{*}{ Empl squared } & -0.0000330 & -0.0000283 & -0.0000057 & -0.0000044 & -0.0000039 & 0.0000027 \\
\hline & $(0.000038)$ & $(0.000065)$ & $(0.000029)$ & $(0.000011)$ & $(0.000012)$ & $(0.000011)$ \\
\hline \multirow[t]{2}{*}{ Plant vintage } & 0.00197 & 0.00517 & 0.000741 & 0.00224 & 0.000984 & $-0.00236^{*}$ \\
\hline & $(0.0046)$ & $(0.0068)$ & $(0.0045)$ & $(0.0017)$ & $(0.0014)$ & $(0.0013)$ \\
\hline \multirow[t]{2}{*}{ Capital intensity } & $-0.267^{* * *}$ & -0.204 & $-0.281^{* * *}$ & $-0.184^{* * *}$ & $-0.132^{* * *}$ & $-0.121^{* *}$ \\
\hline & $(0.096)$ & $(0.21)$ & $(0.11)$ & $(0.039)$ & $(0.040)$ & $(0.051)$ \\
\hline \multirow[t]{2}{*}{ Staff with degree } & -0.00285 & -0.00909 & -0.00144 & 0.00222 & $0.00510^{*}$ & 0.000563 \\
\hline & $(0.0090)$ & $(0.017)$ & $(0.0097)$ & $(0.0037)$ & $(0.0031)$ & $(0.0031)$ \\
\hline \multirow[t]{2}{*}{ Export intensity } & -0.151 & 0.183 & 0.110 & $0.353^{* *}$ & $0.389 * * *$ & $0.314^{*}$ \\
\hline & $(0.36)$ & $(0.67)$ & $(0.36)$ & $(0.14)$ & $(0.15)$ & $(0.18)$ \\
\hline \multirow[t]{2}{*}{ Market share } & $14.18^{* * *}$ & 11.82 & 4.638 & 1.098 & -0.0286 & $-1.826^{* *}$ \\
\hline & $(4.41)$ & $(9.11)$ & $(3.40)$ & $(1.20)$ & $(1.27)$ & $(0.84)$ \\
\hline \multirow{2}{*}{ Innovator } & -2.483 & -1.421 & 2.735 & 0.962 & 0.0675 & -0.0183 \\
\hline & $(3.56)$ & $(5.10)$ & $(2.66)$ & $(0.98)$ & $(1.09)$ & $(1.19)$ \\
\hline \multirow[t]{2}{*}{ HQ in UK } & 0.0274 & -0.108 & 0.0287 & -0.0201 & 0.0910 & 0.219 \\
\hline & $(0.36)$ & $(0.71)$ & $(0.36)$ & $(0.13)$ & $(0.14)$ & $(0.15)$ \\
\hline \multirow[t]{2}{*}{ HQ in US } & 0.542 & 0.413 & 0.469 & $0.267^{* *}$ & 0.0416 & -0.0301 \\
\hline & $(0.34)$ & $(0.70)$ & $(0.35)$ & $(0.13)$ & $(0.14)$ & $(0.18)$ \\
\hline \multirow[t]{2}{*}{ HQ in other country } & -0.206 & -0.283 & 0.113 & -0.0347 & -0.159 & -0.180 \\
\hline & $(0.34)$ & $(0.72)$ & $(0.34)$ & $(0.13)$ & $(0.14)$ & $(0.18)$ \\
\hline \multicolumn{7}{|l|}{ Market Characteristics } \\
\hline \multirow[t]{2}{*}{ Herfindahl Index } & $-8.495^{* * *}$ & -4.628 & -0.349 & -0.391 & 0.572 & 0.408 \\
\hline & $(1.80)$ & $(4.97)$ & $(1.91)$ & $(0.72)$ & $(0.61)$ & $(0.66)$ \\
\hline \multirow{2}{*}{ Sector Innovation intensity } & 1.429 & -3.746 & 3.384 & $3.170^{*}$ & $3.048^{*}$ & 1.138 \\
\hline & $(4.43)$ & $(8.55)$ & $(4.37)$ & $(1.75)$ & $(1.68)$ & $(2.12)$ \\
\hline Industry and Location Dumm & & & & & & \\
\hline Textiles & 0.169 & 1.296 & -0.224 & $-0.334^{*}$ & -0.115 & -0.243 \\
\hline & $(0.49)$ & $(1.01)$ & $(0.49)$ & $(0.19)$ & $(0.19)$ & $(0.25)$ \\
\hline Wood & -0.466 & 0.337 & 0.228 & -0.0704 & 0.113 & 0.237 \\
\hline & $(0.71)$ & $(0.88)$ & $(0.72)$ & $(0.27)$ & $(0.25)$ & $(0.22)$ \\
\hline Paper & 0.485 & 0.577 & $1.004^{*}$ & $0.623^{* * *}$ & $0.551^{* *}$ & 0.388 \\
\hline & $(0.57)$ & $(1.03)$ & $(0.56)$ & $(0.23)$ & $(0.23)$ & $(0.27)$ \\
\hline Chemicals & 0.331 & 1.023 & 0.254 & 0.0545 & 0.117 & 0.174 \\
\hline & $(0.47)$ & $(1.00)$ & $(0.48)$ & $(0.19)$ & $(0.19)$ & $(0.24)$ \\
\hline Metals & 0.163 & 1.049 & 0.493 & 0.148 & 0.214 & 0.0310 \\
\hline & $(0.44)$ & $(0.93)$ & $(0.45)$ & $(0.18)$ & $(0.18)$ & $(0.21)$ \\
\hline Machinery & 0.219 & 0.777 & 0.00822 & -0.0428 & 0.0175 & 0.109 \\
\hline & $(0.51)$ & $(0.96)$ & $(0.48)$ & $(0.20)$ & $(0.20)$ & $(0.24)$ \\
\hline Electrical & -0.311 & 0.758 & -0.696 & $-0.747^{* * *}$ & -0.442 & -0.340 \\
\hline & $(0.71)$ & $(1.57)$ & $(0.70)$ & $(0.28)$ & $(0.27)$ & $(0.34)$ \\
\hline Transport & -0.205 & 0.192 & -0.281 & -0.123 & -0.245 & -0.385 \\
\hline & $(0.67)$ & $(1.38)$ & $(0.67)$ & $(0.26)$ & $(0.24)$ & $(0.34)$ \\
\hline Northern Ireland & -0.0563 & -0.344 & -0.196 & $-0.177^{*}$ & -0.0293 & 0.0578 \\
\hline & $(0.25)$ & $(0.45)$ & $(0.26)$ & $(0.099)$ & $(0.099)$ & $(0.11)$ \\
\hline Specification test for selection & 1.255 & & & & & \\
\hline m(n) & $(1.84)$ & & & & & \\
\hline Selection hazard Note 3 & & 0.680 & -1.253 & -0.428 & -0.109 & -0.0280 \\
\hline & & $(2.55)$ & $(1.33)$ & $(0.49)$ & $(0.52)$ & $(0.56)$ \\
\hline Constant & 0.446 & -1.485 & $-4.887^{* *}$ & $-2.848^{* * *}$ & $-1.766^{*}$ & -0.898 \\
\hline & $(3.16)$ & $(4.93)$ & $(2.43)$ & $(0.89)$ & $(0.97)$ & $(1.10)$ \\
\hline Observations & 356 & 356 & 356 & 356 & 356 & 356 \\
\hline
\end{tabular}


of atanh(rho) is equivalent to the test of the null of rho=1. Insignificant atanh(rho) indicates that selectivity bias is negligible.

Note 3: The reported coefficient of selection hazard is lambda, the parameter estimate on the selection hazard from the augmented regression using Maddala (1983) formulas, more specifically, lambda $=$ rho*sigma, where sigma is the standard deviation of residual term in the primary equation (profitability equation in this case). 
Table 5: Determinants of profitability: split sample estimation

\begin{tabular}{|c|c|c|c|}
\hline COEFFICIENT & $\begin{array}{l}\text { Indigenous non- } \\
\text { innovators }\end{array}$ & $\begin{array}{l}\text { Indigenous } \\
\text { innovators }\end{array}$ & $\begin{array}{l}\text { Externally-owned } \\
\text { innovators }\end{array}$ \\
\hline \multicolumn{4}{|l|}{ Plant Characteristics } \\
\hline \multirow[t]{2}{*}{ Employment } & -0.00382 & -0.00458 & 0.000107 \\
\hline & $(0.0026)$ & $(0.0037)$ & $(0.00042)$ \\
\hline \multirow[t]{2}{*}{ Empl squared } & 0.000992 & 0.000547 & -0.0000204 \\
\hline & $(0.00061)$ & $(0.00042)$ & $(0.000022)$ \\
\hline \multirow[t]{2}{*}{ Plant vintage } & 0.00275 & 0.00224 & 0.000890 \\
\hline & $(0.0021)$ & $(0.0027)$ & $(0.0028)$ \\
\hline \multirow[t]{2}{*}{ Capital intensity } & 0.0134 & $-0.119 * *$ & $-0.321^{* * *}$ \\
\hline & $(0.066)$ & $(0.046)$ & $(0.11)$ \\
\hline \multirow[t]{2}{*}{ Staff with degree } & -0.000392 & 0.000577 & 0.00112 \\
\hline & $(0.0060)$ & $(0.0036)$ & $(0.0061)$ \\
\hline \multirow[t]{2}{*}{ Export intensity } & 0.200 & 0.268 & -0.0914 \\
\hline & $(0.26)$ & $(0.28)$ & $(0.39)$ \\
\hline \multirow[t]{2}{*}{ Market share } & -18.50 & 24.26 & 16.20 \\
\hline & $(14.8)$ & $(25.1)$ & $(12.8)$ \\
\hline \multirow[t]{2}{*}{$\mathrm{HQ}$ in UK } & & & -0.00188 \\
\hline & & & $(0.21)$ \\
\hline \multirow[t]{2}{*}{ HQ in US } & & & $0.505^{*}$ \\
\hline & & & $(0.28)$ \\
\hline \multirow[t]{2}{*}{$\mathrm{HQ}$ in other countries } & & & -0.306 \\
\hline & & & $(0.25)$ \\
\hline \multicolumn{4}{|l|}{ Market Characteristics } \\
\hline \multirow[t]{2}{*}{ Herfindahl Index } & 0.777 & $2.557^{* *}$ & -9.628 \\
\hline & $(0.48)$ & $(1.09)$ & $(9.18)$ \\
\hline \multirow[t]{2}{*}{ Sector Innovation intensity } & -3.507 & -0.730 & 1.109 \\
\hline & $(3.05)$ & (1.98) & $(2.43)$ \\
\hline \multicolumn{4}{|l|}{$\begin{array}{l}\text { Industry and Location } \\
\text { Dummies }\end{array}$} \\
\hline \multirow[t]{2}{*}{ Textiles } & $0.698^{* * *}$ & -0.593 & 0.254 \\
\hline & $(0.25)$ & $(0.57)$ & $(0.38)$ \\
\hline \multirow[t]{2}{*}{ Wood } & $0.647^{* *}$ & -0.143 & -0.601 \\
\hline & $(0.29)$ & $(0.29)$ & $(0.68)$ \\
\hline \multirow[t]{2}{*}{ Paper } & 0.269 & $0.367^{*}$ & 0.393 \\
\hline & $(0.29)$ & $(0.21)$ & $(0.39)$ \\
\hline \multirow[t]{2}{*}{ Chemicals } & $0.672^{* *}$ & $0.632^{* * *}$ & 0.376 \\
\hline & $(0.28)$ & $(0.14)$ & $(0.26)$ \\
\hline \multirow[t]{2}{*}{ Metals } & $0.605^{* * *}$ & $0.329 * *$ & 0.118 \\
\hline & $(0.21)$ & $(0.16)$ & $(0.27)$ \\
\hline \multirow[t]{2}{*}{ Machinery } & $0.729 * * *$ & 0.220 & 0.148 \\
\hline & $(0.28)$ & $(0.14)$ & $(0.26)$ \\
\hline Electrical & $0.588^{*}$ & 0.276 & -0.317 \\
\hline & $(0.35)$ & $(0.26)$ & $(0.41)$ \\
\hline Transport & $1.079 * * *$ & -0.328 & -0.320 \\
\hline & $(0.27)$ & $(0.37)$ & $(0.40)$ \\
\hline Northern Ireland & -0.0667 & $-0.249^{*}$ & -0.160 \\
\hline & $(0.12)$ & $(0.14)$ & $(0.16)$ \\
\hline Constant & $-1.569 * * *$ & $-1.440^{* * *}$ & $-1.531^{* * *}$ \\
\hline & $(0.47)$ & $(0.43)$ & $(0.57)$ \\
\hline Observations & 202 & 624 & 320 \\
\hline $\mathrm{R}^{2}$ & & 0.16 & 0.17 \\
\hline Estimator & Random effect & Pooled & Pooled \\
\hline BP LM test P-value & 0.008 & 0.76 & 0.8473 \\
\hline
\end{tabular}


Note 1: All regressions including time dummies. Standard errors in parentheses; ${ }^{* * *} \mathrm{p}<0.01,{ }^{* *} \mathrm{p}<0.05,{ }^{*}<0.1$.

Note 2: The reported selection mechanism (atanh(rho)) is the inverse hyperbolic tangent of the correlation coefficien rho between residual terms of main equation and selection equation, i.e. $\operatorname{atanh}(\mathrm{rho})=0.5[\ln (1+\mathrm{rho}) /(1-\mathrm{rho})]$. The test of atanh(rho) is equivalent to the test of the null of rho=1. Insignificant atanh(rho) indicates that selectivity bias is negligible.

Note 3: The reported coefficient of selection hazard is lambda, the parameter estimate on the selection hazard from the augmented regression using Maddala (1983) formulas, more specifically, lambda = rho*sigma, where sigma is the standard deviation of residual term in the primary equation (profitability equation in this case). 


\section{References}

Anyadike-Danes, M and Heller, S (2006) 'How Is Competitiveness Distributed In Irish Industries?’ All Island Business Model Working Paper 4, ERINI, Belfast.

Barry F and Bradley J (1997) 'FDI and Trade: The Irish Host-Country Experience' Economic Journal, 107, 1798-1811.

Bartelsman, E.J. and M. Doms (2000), "Understanding productivity: lessons from longitudinal microdata", Journal of Economic Literature, Vol. 38, pp. 569-595.

Birnie, E and Hitchens, D M W N (1998) 'Productivity and Income per capita. Convergence in Peripheral European Economy: The Irish Experience', Regional Studies, 32, 223-234.

Brugger E A and Stuckey B (1987) 'Regional economic structure and innovative behaviour in Switzerland', Regional Studies, 21, 241-254.

Buckley, P.J. and Casson, M.C. (1976). The Future of the Multinational Enterprise. London: Macmillan Press.

Buisseret TJ, Cameron H and Georghiou L (1995) 'What difference does it make? Additionality in the public support of R\&D in large firms', International Journal of Technology Management, 10, 587-600

Cassidy, M (2004) 'Productivity in Ireland: Trends and Issues', Quarterly Bulletin, Spring 2004, 83-105.

Cassidy, M, Görg, H and Strobl, E, (2005), 'Knowledge accumulation and productivity: Evidence from plant-level data for Ireland', Scottish Journal of Political Economy, Vol.52, 344-358.

Caves, R E. (1996) Multinational Enterprise and Economic Analysis. 2nd ed., Cambridge: Cambridge University Press.

Caves, R. E. (1998), 'Industrial Organization and New Findings and the Turnover and Mobility of Firms', Journal of Economic Literature, 36, 4, 1947-82.

Cefis E and Ciccarelli M (2005) 'Profit differentials and innovation', Economics of Innovation and New Technology, 14, 43-61.

Crépon, B., Duguet, E., and J. Mairesse (1998) 'Research, Innovation and Productivity: An econometric analysis at the firm level', Economics of Inovation and New Technology, 7, 115-158.

D’Este P (2005) 'How do firms' knowledge bases affect intra-industry heterogeneity? An analysis of the Spanish pharmaceutical industry', Research Policy, 34, 33-45. 
DETI (2005) Edition 8 - Facts and Figures from the IDBR, Department of Enterprise Trade and Investment, Belfast. Available at:

http://www.detini.gov.uk.

Driffield, N and Girma, S (2003) 'Regional Foreign Direct Investment and Wage Spillovers: Plant Level Evidence from the UK Electronics Industry', Oxford Bulletin of Economics and Statistics, 65(4), 453-474.

Dunning J (1988) Explaining International Production, Unwin Hyman, London.

Forfas (2006) 'Enterprise Statistics at a Glance, 2006', Forfas, Dublin. Available at: www.forfas.ie.

Geroski P and Machin S (1992) 'Do innovating firms outperform non-innovators?', Business Strategy Review, Summer, 79-90.

Geroski P , Machin S and Van Reenen J (1993) 'The profitability of innovating firms', RAND Journal of Economics, 24 198-211.

Geroski P, Van Reenen J and Walters C F (1997) 'How persistently do firms innovate?' Research Policy, 26, 33-48

Girma S and Görg, H (2005) 'Foreign direct investment, spillovers and absorptive capacity:evidence from quantile regressions' Deutsche Bundesbank Discussion Paper $13 / 2005$.

Girma S, Görg H and Strobl E (2004) 'Exports, International Investment, and Plant Performance: Evidence from a Non-parametric Test, Economics Letters, 83, 317-324.

Globerman, Steven, John C. Ries, and Vertinsky, Ilan (1994) 'The Economic Performance of Foreign Affiliates in Canada', Canadian Journal of Economics, 27(1), $143-156$.

Goddard J, Tavakoli M and Wilson J O S (2006) 'Determinants of profitability in European manufacturing and services: evidence from a dynamic panel model', Applied Financial Economics, 15, 1269-1282.

Görg H and Strobl E (2003) 'Multinational Companies, Technology Spillovers and Plant Survival, Scandinavian Journal of Economics, 105, 591-595.

Görg H and Strobl E (2002) 'Multinational Companies and Indigenous Development: An Empirical Analysis', European Economic Review, 46, 1305-1322.

Greene, W.H. (2005), Econometric Analysis (5 ${ }^{\text {th }}$ ed.). Prentice-Hall, New Jersey

Greenaway D and Kneller R (2004) 'Exporting and productivity in the United Kingdom', Oxford Review of Economic Policy, 20, 358-371. 
Griffith R, Redding S and Simpson H (2004) 'Foreign ownership and productivity: new evidence from the service sector and the R\&D lab', Oxford Review of Economic Policy, 20, 440-456.

Hanel P and St-Pierre A (2002) 'Effects of R\&D spillovers on the profitability of firms', Review of Industrial Organization, 20, 305-322.

Harris R I D and Trainor M (1995) 'Innovations and R\&D in Northern Ireland manufacturing: a Schumpeterian approach’, Regional Studies, 29, 593-604.

Hemphill, T A (2003) 'Cooperative Strategy, Technology Innovation and Product Development in Industrial Companies', International Journal of Production Economics, 69, 169-76.

Hewitt-Dundas, H, Andréosso-O'Callaghan, B, Crone, M, Roper, S (2005) 'Knowledge Transfers from Multi-national Plants in Ireland - A Cross-border Comparison of Supply Chain Linkages', European Urban and Regional Studies, 12, 23-43.

Horn, Paul M (2005) 'The Changing Nature of Innovation', Research Technology Management, 48, 28-33.

Horstmann, I.J. and Markusen, J.R. (1996) 'Exploring new markets: Direct investment, contractual relations and the multinational enterprise', International Economic Review, Vol. 37, No. 1, pp. 1-19.

Howells J (1984) 'The location of research and development: some observations and evidence from Britain', Regional Studies, 18, 13-29.

Joshi, A W and Sharma, S (2004) 'Customer Knowledge Development: Antecedents and Impact on New Product Performance’, Journal of Marketing, 68, 47-59.

Koenker, R. and G. Bassett (1978), "Regression quantiles", Econometrica, Vol. 50, pp.43-61.

Leiponen A (2000) 'Competencies, innovation and profitability of firms', Economics of Innovation and New Technology, 9, 1-24.

Link, A N Paton, D and Siegel, D S (2005) 'An Econometric Analysis of Trends in Research Joint Venture Activty', Managerial and Decision Economics, 26, 149-158.

Lööf, H. and A. Heshmati (2002), 'Knowledge capital and performance heterogeneity: A firm level innovation study', International Journal of Production Economics, 76, 61-85.

Love J H and Ashcroft B (1999) 'Market versus corporate structure in plant-level innovation performance', Small Business Economics, 13, 97-109. 
Love J H, Ashcroft B and Dunlop S (1996) 'Corporate structure, ownership and the likelihood of innovation', Applied Economics, Vol 28, 737-46.

Love J H and Roper S (2001) "Location and network effects on innovation success: evidence for UK, German and Irish manufacturing plants", Research Policy, 30, 643661.

Maddala, G (1983) Limited Dependent and Qualitative Variables in Econometrics, Cambridge University Press, New York.

Malecki E J (1980) 'Corporate organisation of R\&D and the location of technological activities', Regional Studies, 14, 219-234.

Oulton, N. (2001) 'Why do foreign-owned firms have higher labour productivity?' in Pain, N. (ed) Inward Investment, Technological Change and Growth, Palgrave, London

Roberts P W (1999) 'Product innovation, product-market competition and persistent profitability in the US pharmaceutical industry', Strategic Management Journal, 20, 655-670.

Roper, S and Anderson, J (2000) 'Innovation and E-Commerce - A Cross-Border Comparison of Irish Manufacturing Plants', NIERC Research Report 17, Belfast.

Roper S, Ashcroft B, Love J H, Dunlop S, Hofmann H, Vogler-Ludwig K, (1996) 'Product Innovation and Development in UK, German and Irish Manufacturing', Queen's University of Belfast/University of Strathclyde/ifo Institut.

Roper S, Du J and Love J H (2006) 'The innovation value chain', Aston Business School Research Paper RP 0605, Birmingham.

Roper, S and Hewitt-Dundas, N, (1998) 'Benchmarking Company Profitability and Growth: Some Measurement Issues for Small Firms in Ireland', Economic and Social Review, 29, 2, pp. 201-208.

Roper, S and Hewitt-Dundas, N (2005) 'Measuring the Impact of Grant Support for Innovation: Panel Data Evidence for Irish Firms', European Regional Science Association, Amsterdam, August 2005.

Roper, S Hewitt-Dundas, N and Love, J H (2004) 'An Ex Ante Evaluation Framework for the Regional Benefits of Publicly Supported R\&D Projects', Research Policy, 33, 487-509.

Stone, I. and Peck, F. (1996) "The foreign-owned manufacturing sector in UK peripheral regions, 1978-1993: Restructuring and comparative performance", Regional Studies, 30, 55-68. 
Wrynn, J (1997) 'Foreign Direct Investment to a Peripheral Country - The Case of Ireland' in Fynes, B and Ennis, S (eds) Competing From the Periphery, Oaktree Press, Dublin. 


\section{Appendix: Normality tests}

\section{Figure A1: All plants}

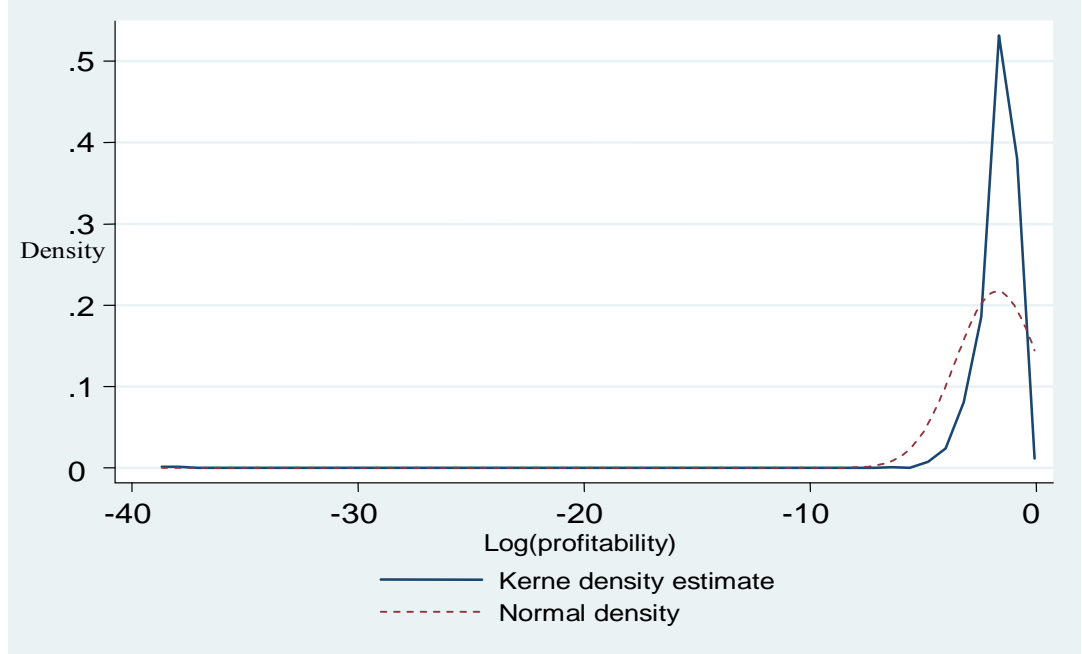

Figure A2: Indigenous non-innovators

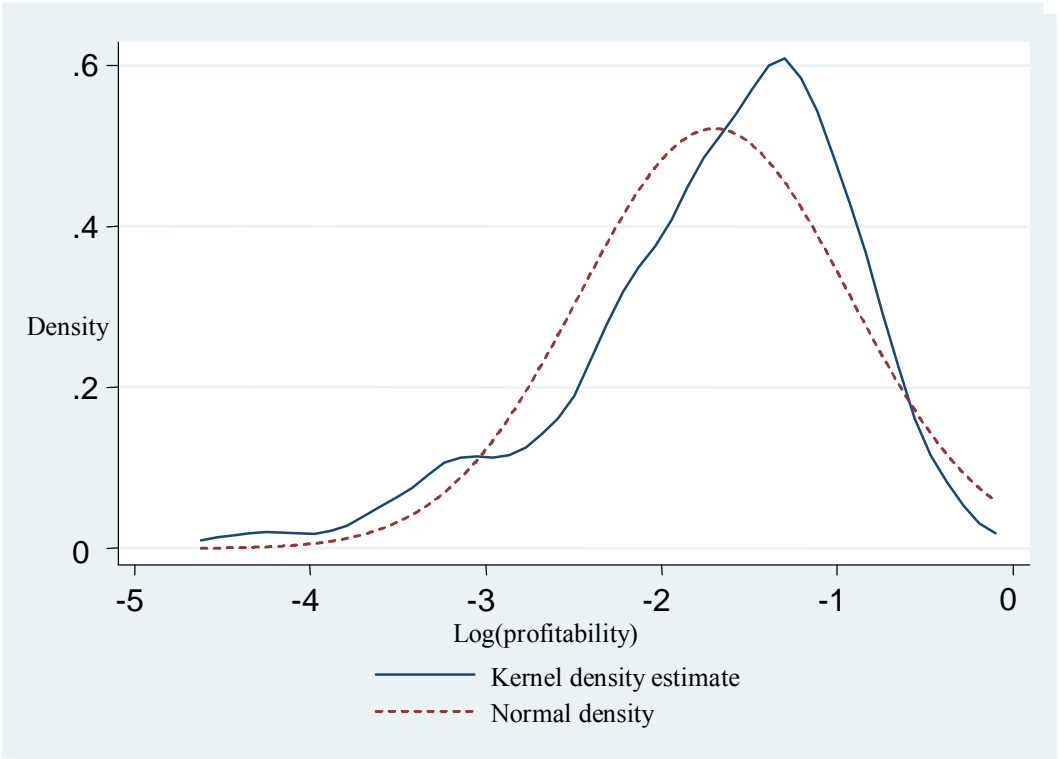


Figure A3: Indigenous innovators

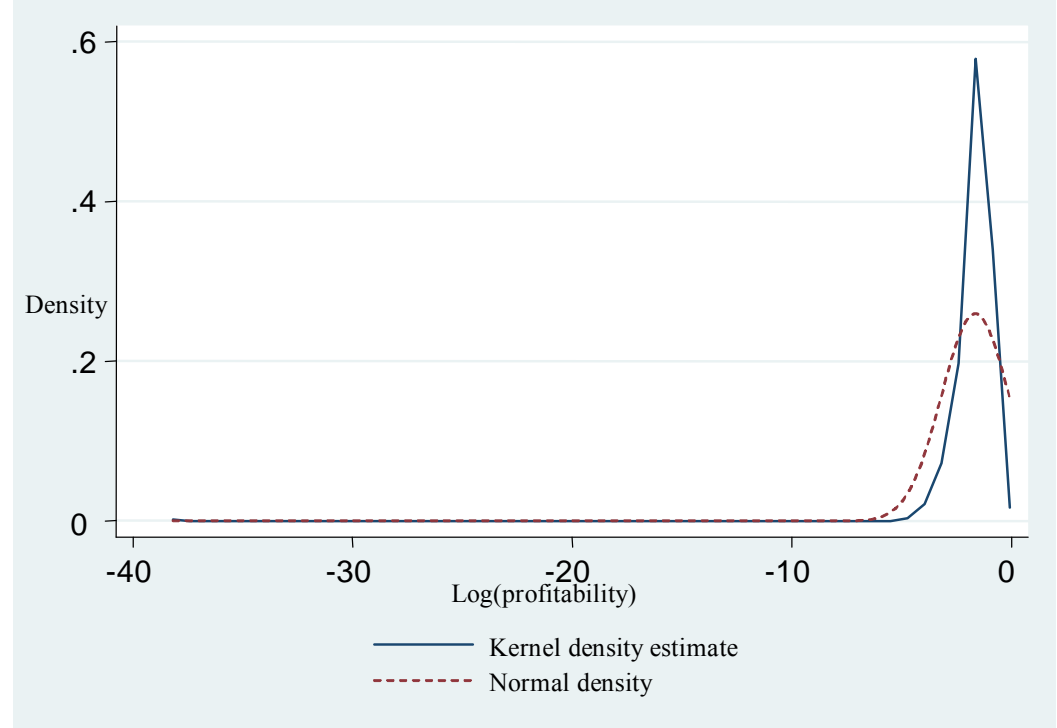

Figure A4: Externally-owned plants

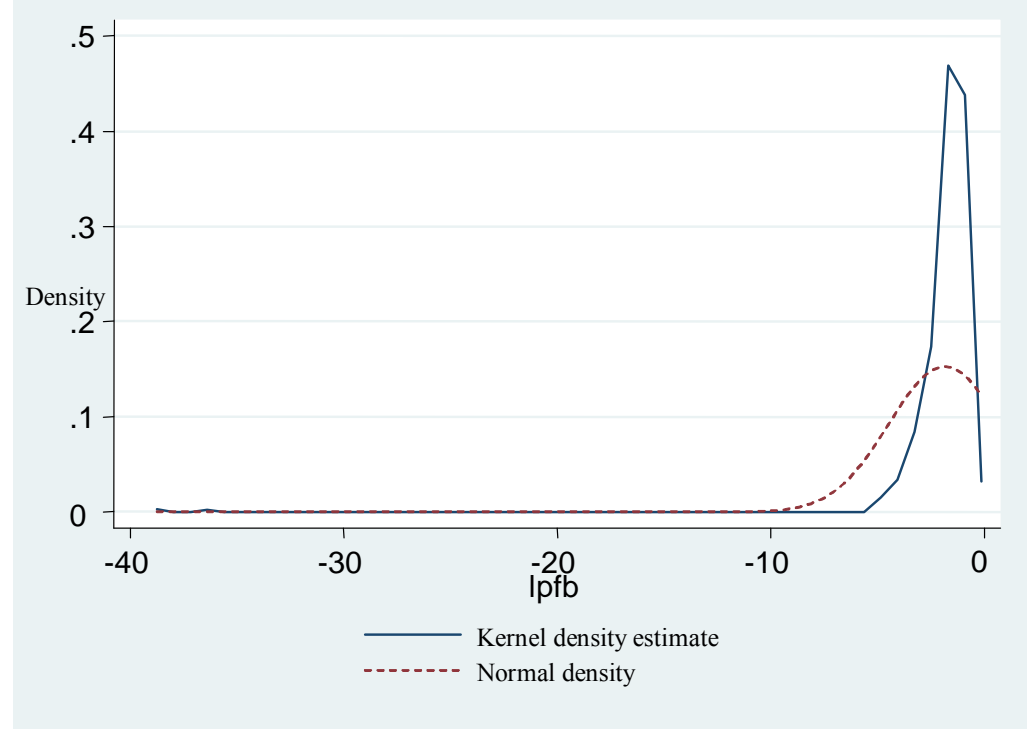

Table A1: test statistics

\begin{tabular}{|l|l|l|r|r|}
\hline & $\begin{array}{l}\text { All } \\
\text { plants }\end{array}$ & $\begin{array}{l}\text { Indigenous } \\
\text { non- } \\
\text { innovators }\end{array}$ & \multicolumn{1}{|l}{$\begin{array}{l}\text { Indigenous } \\
\text { innovators }\end{array}$} & $\begin{array}{l}\text { Externally- } \\
\text { owned }\end{array}$ \\
mean & -1.72812 & -1.700074 & -1.657758 & -1.866473 \\
median & -1.51676 & -1.544899 & -1.504077 & -1.520675 \\
std dev & 1.836422 & 0.7652626 & 1.536543 & 2.614199 \\
Skewness & -16.136 & -0.9611405 & -18.41698 & -12.17776 \\
Kurtosis & 315.6822 & 3.903376 & 433.4762 & 166.7301 \\
Observation & 1410 & 263 & 725 & 422 \\
Skewness/Kurtosis tests (D'Agostino et al, 1990) for Normality & \\
Pr(Skewness) & 0.000 & 0.000 & 0.000 & 0.000 \\
Pr(Kurtosis) & 0.000 & 0.000 & 0.015 & 0.000 \\
Shapiro-Francia (Shapiro and Francia, 1972) W' test for normal data \\
P-value & 0.00001 & 0.00001 & 0.00001 & 0.00001 \\
\hline
\end{tabular}


Table A2: Correlation between HHI and industrial dummies.

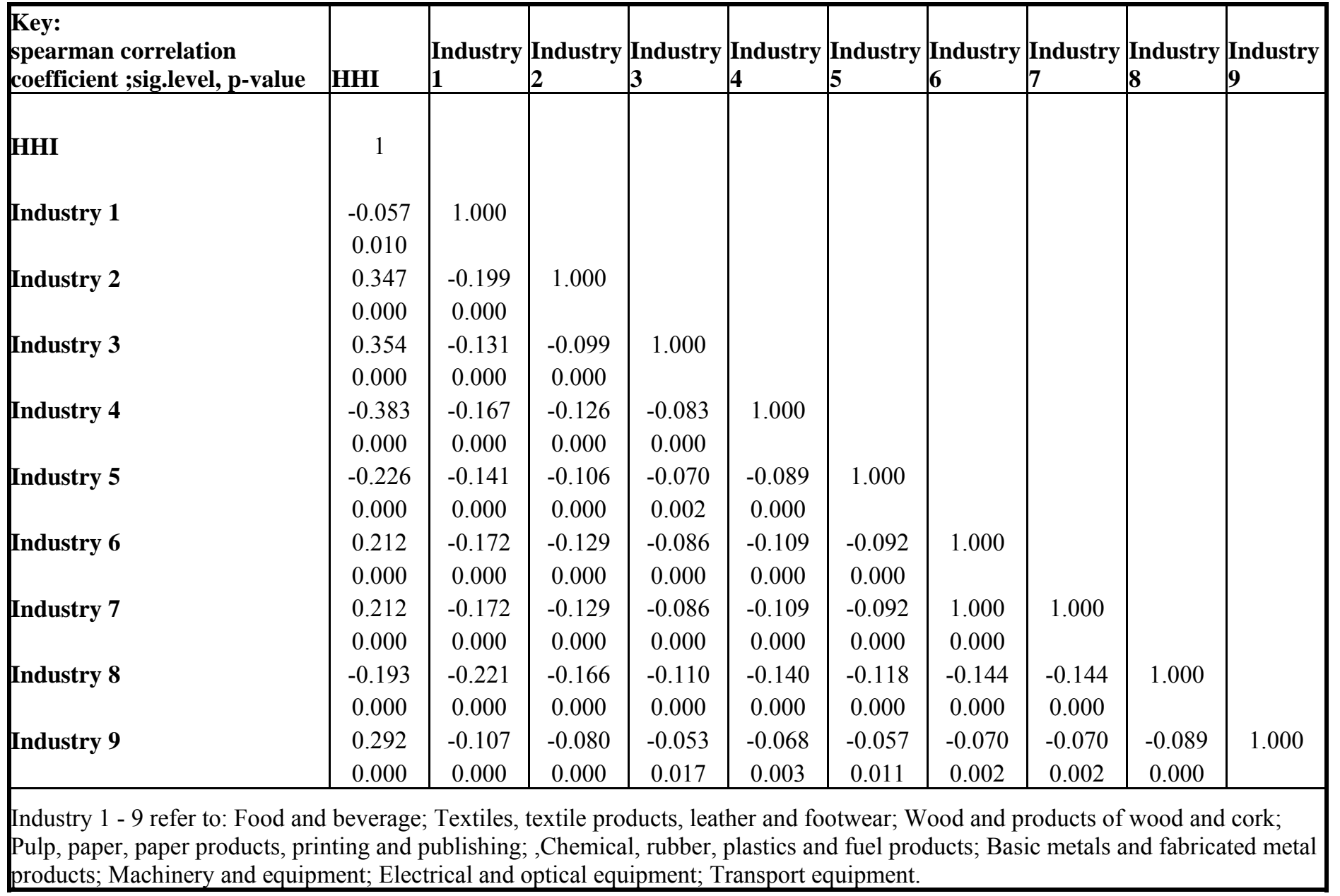

